\title{
New records of Vertigo moulinsiana (Gastropoda: Vertiginidae) and notes on its distribution and habitats in the Czech Republic
}

\author{
LUBOŠ BERAN
}

KokořiínskoProtected Landscape Area Administration,,Česká 149, CZ-27601 Mělník, Czech Republic, e-mail:

lubos.beran@schkocr.cz

BERAN L., 2006: New records of Vertigo moulinsiana (Gastropoda: Vertiginidae) and notes on its distribution and habitats in the Czech Republic - Malacologica Bohemoslovaca, 5: 14-17. Online serial at $<$ http://mollusca.sav.sk $>$ 21-Apr-2006.

Vertigo moulinsiana (Dupuy, 1849) was found in 2003-2005 in Northern Bohemia (Czech Republic) at 11 sites. All these sites are situated on floodplains of smaller streams in a sandstone area. The known occurrence of this endangered relict in the Czech Republic is concentrated in three areas - a large area of Bohemian Cretaceous Basin, a floodplain near villages Břežany and Božice (Dyje River Basin) in Southern Moravia and small, isolated, treeless fens in the White Carpathians (Bílé Karpaty Mts.). The principal habitats where $V$. moulinsiana lives in the Czech Republic are sedge marshes, Typha swamps, reed swamps (with Carex spp.), alder carrs (also with Carex spp.) and tufa-forming spring fens.

\section{Introduction}

Vertigo moulinsiana (Dupuy, 1849) is considered to be an Atlantic-Mediterranean species, with continuos range in Southern Europe (mainly France) and isolated sites in Central Europe, Iberian Peninsula and - outside Europe - in Northern Africa (PoKRYSZKO 2003). This species mainly inhabits calcareous, lowland wetlands (CAMERON et al. 2003). In contrast to most other species of the genus Vertigo, it prefers especially permanent wet sites. $V$. moulinsiana is regarded as globally threatened (POKRYSZKO 2003) and is considered to be a relict from the Late Holocene, when it inhabited the extensive wetlands, which occurred during this period (LOŽEK 1955). The decline of its occurrence was probably caused by the loss of suitable wetlands, primarily due to climatic changes and later mainly resulting from human activities.

\section{Distribution in the Czech Republic}

Despite the common occurrence in the Late Holocene (e. g. LOŽEK 1955) $V$. moulinsiana was considered to be extinct in the Czech Republic due to climatic changes and loss of suitable habitats. The first living population was discovered by B. Zvarič in Southern Moravia near Břežany village in 1965 (FLASAR \& ZVARIČ 1966) and later (1968) near Božice village (ZVARIČ, unpubl.). Thirty years later (1994) large populations were found in extensive wetlands along brooks Liběchovka and Pšovka in the Kokorrínsko Protected Landscape Area (Central and Northern Bohemia) by BERAN (1995). Recently more than 60 sites with its occurrence have been documented from this area (BERAN in press). $V$. moulinsiana was later found at 3 new sites in the White Carpathians, where this snail inhabits small isolated calcareous fens (HORSÁK 2005).

Nearly all these sites were included among pSCI (proposed Sites of the Community Importance) and many of them are also situated within protected 
areas of different categories (Protected Landscape Area, National Nature Reserve, National Nature Monuments, Nature Reserve, Nature Monument).

\section{New records}

Vertigo moulinsiana was found in 2003-2005 in Northern Bohemia in new sites listed below. Presented data are as follows - geographical coordinates, code of the mapping field for faunistic grid mapping (cf. PRUNER \& MíKA 1996), altitude, name of the nearest settlement, description of the site, habitat, number of individuals, date of investigation:

1 - 50³0'00" N, 1451'59" E, 5555, 230 m, Bělá pod Bezdězem, southern part of the Valcha pond near a railway, sedge marshes and tufts of $C$. paniculata, a) 10 specimens, 1 Oct 2003; b) 6 specimens, 12 Oct 2004;

2 - 50³0'03" N, 1451'55" E, 5455, 230 m, Bělá pod Bezdězem, northern part of the Valcha pond near a railway, sedge marshes and tufts of $C$. paniculata, 5 specimens, 12 Oct 2004;

3 - 50²9'48" N, 1454'26" E, 5555, 213 m, Velký Rečkov, Rečkov National Nature Monument, sedge marshes and alder carrs, 6 specimens, 4 Oct 2004; 4 - 50²9'42" N, 1454'35" E, 5555, 213 m, Velký Rečkov, wetland on the south-eastern boundary of Rečkov NNM outside the NNM, sedge marshes, 17 specimens, 4 Oct 2004;

5 - 50²9'40" N, 1454'37" E, 5555, 213 m, Velký Rečkov, wetlands among the south-eastern bound- ary of Rečkov NNM and a railway, alder carrs with Carex sp, reed swamps, sedge marshes, 5 specimens, 4 Oct 2004;

$6-50^{\circ} 29^{\prime} 37^{\prime \prime} \mathrm{N}, 14^{\circ} 54^{\prime} 30^{\prime \prime} \mathrm{E}, 5555,213$ m, Velký Rečkov, wetland among the Bělá stream, a railway and a road on the eastern boundary of Velký Rečkov, alder carrs with Carex spp., 4 specimens, 4 Oct 2004;

7 - 50²9'49" N, 1453'28" E, 5555, 215 m, Velký Rečkov, Klokočka National Nature Monument, sedge marshes, alder carrs with Carex spp., 5 specimens, 12 Oct 2004;

8 - 50³6'48" N, 144ㄴ' $51^{\circ}$ " E, 5354, 265 m, Hradčany, wetland in the eastern edge of the Hradčanský Rybník pond in the Hradčanské Rybníky Nature Reserve, alder carrs with Carex spp., 10 specimens, 5 May 2005;

9 - 50³4'21" N, 14³9'14" E, 5453, 266 m, Doksy, wetland on the border of the Dokeská Zátoka cove, tufts of $C$. paniculata bordering Máchovo Jezero pond (water level overstepped $1 \mathrm{~m}$ above the ground surface level), 35 specimens, 4 Aug 2005 ;

$10-50^{\circ} 36^{\prime} 47^{\prime \prime} \mathrm{N}, 14^{\circ} 35^{\prime} 31^{\prime \prime} \mathrm{E}, 5353,252 \mathrm{~m}$, Jestřebí, wetland on the left side of the road Jestřebí Provodín in the Novozámecký Rybník National Nature Reserve, alder carrs with Carex spp., 25 specimens, 16 Aug 2005;

11 - 50³6'41" N, 143'ㄴ' $21^{\prime \prime}$ E, 5353, 252 m, Jestřebí, wetland on the left side of the road Jestřebí Provodín in the Novozámecký Rybník National Nature Reserve, sedge marshes, 4 specimens, 16 Aug 2005.

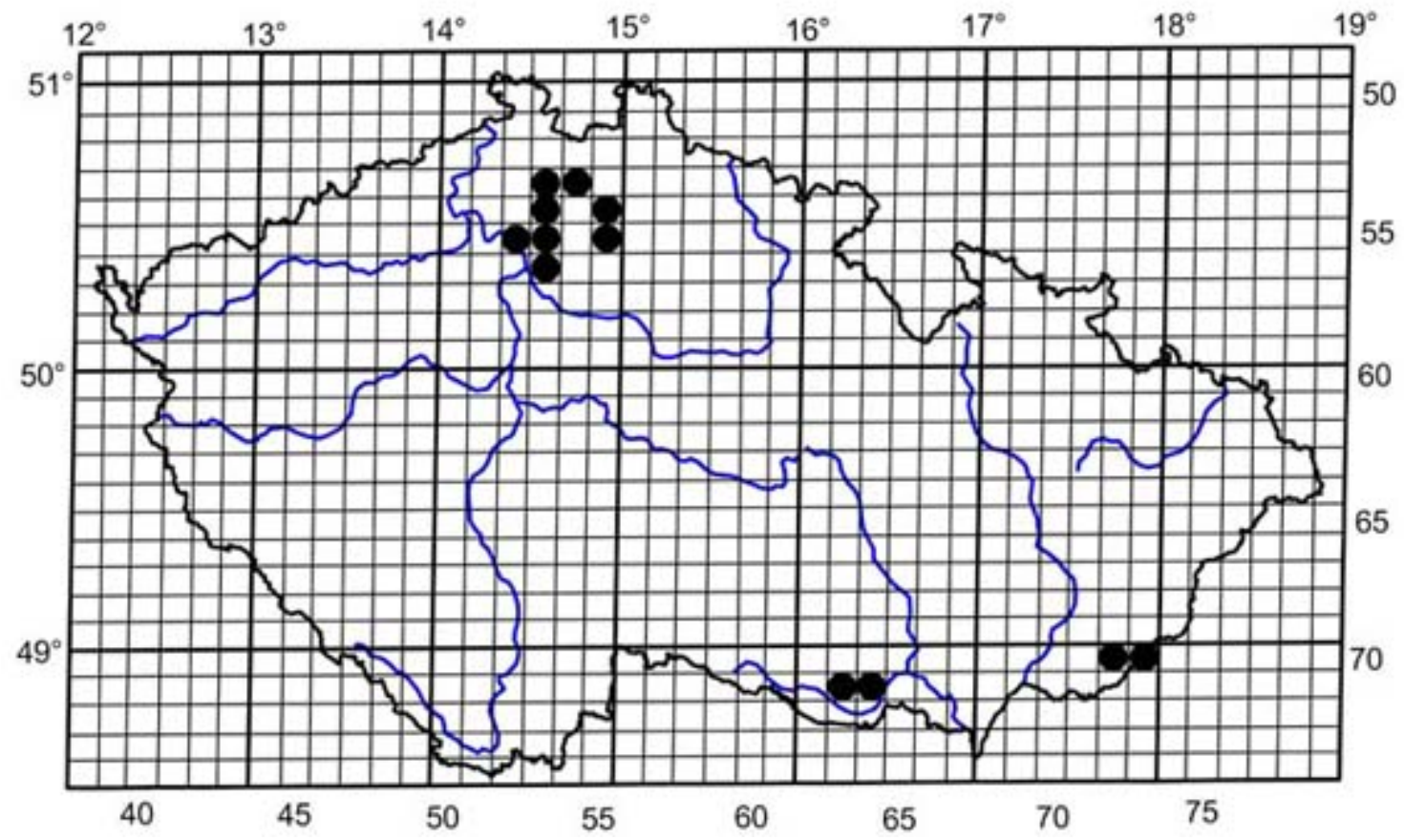

Fig. 1. Faunistic grid map showing the distribution of Vertigo moulinsiana in the Czech Republic. Orig. V. Nedbal. 
All 11 new sites are situated in floodplains of smaller streams in a sandstone area with similar character as the sites where $V$. moulinsiana occurs in the Kokorrínsko PLA. Especially in the case of last new four sites (loc. 8-11) presented above the findings of other sites with $V$. moulinsiana are possible due to the large area of wetlands in their surroundings.

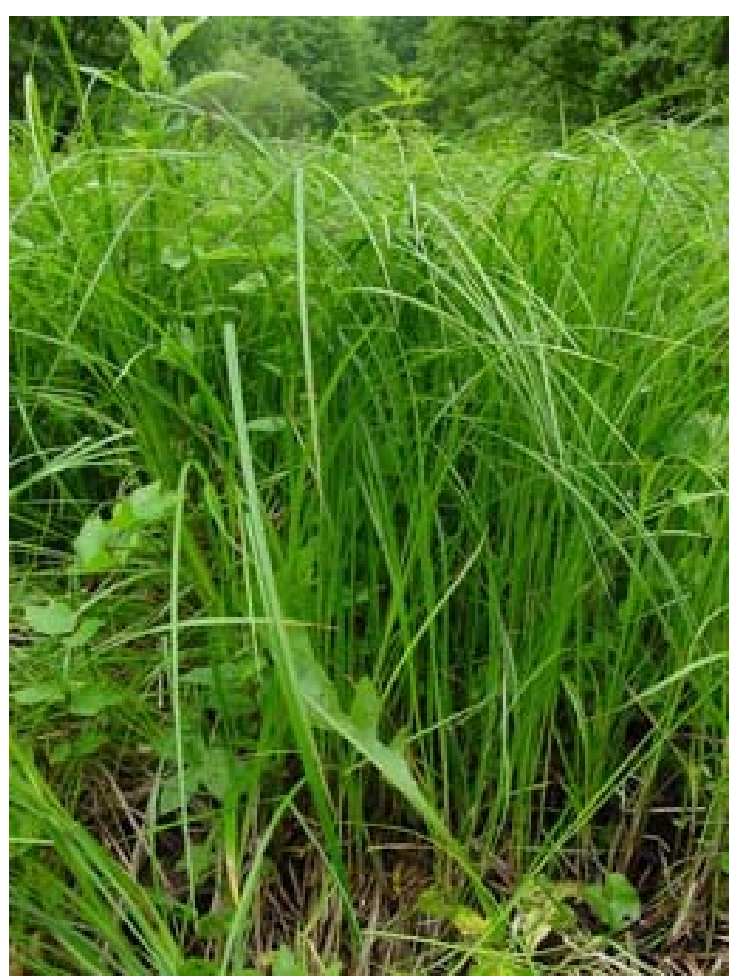

Fig. 2. Sedge marshes (Kokořínsko PLA). Photo L. Beran.

All new sites, many of which are also situated in existing protected areas (National Nature Reserve, National Nature Monuments, Nature Reserve), have been included in pSCI and $V$. moulinsiana has been listed as a protected species.

\section{Habitats}

Vertigo moulinsiana belongs to unihabitat species occurring only in wetlands (POKRYSZKO 2003). In Britain, $V$. moulinsiana lives in permanently wet, usually calcareous, swamps, fens and marshes, bordering rivers, lakes or ponds, or in river floodplains, most often in open situations (KILLEEN 2003). Similar situations are documented from other countries (e. g. POKRYSZKO 1990, CAMERON et al. 2003).



Fig. 3. Alder carr with Carex spp. (Kokořínsko PLA). Photo L. Beran.

The principal habitats where $V$. moulinsiana lives in Bohemia are sedge marshes, reed swamps (with Carex spp.), alder carrs (also with Carex spp.) and calcareous fens. General distribution of habitats of particular sites with the occurrence of $V$. Moulinsiana in Bohemia is shown in Table 1. In all habitats the occurrence of $V$. moulinsiana depends on hydrological conditions, and higher densities were documented in wetter parts where water levels were at the ground surface or very close to it. In the case of tufts of $C$. paniculata or $C$. appropinquata this snail occurs in places where water level often overstepped $1 \mathrm{~m}$ above the ground surface level (e.g. loc. No. 9).

Table 1. General distribution of habitats with occurrence of $V$. moulinsiana at particular sites in Bohemia. $\mathrm{SM}$ - sedge marshes, RS - reed swamps (usually with Carex spp.), AC - alder carrs (with Carex spp.), $\mathrm{CF}$ - calcareous fens; SP - spring, BP - border of pond, BB - border of brook; • - less than $10 \%$ of a total area with occurrence of $V$. moulinsiana, $\bullet \bullet-10-25 \%, \bullet \bullet \bullet-$ more than $25 \%$.

\begin{tabular}{|l|c|c|c|c|c|c|c|}
\hline Site & SM & RS & AC & CF & SP & BP & BB \\
\hline $1-2-$ Valcha Pond & $\bullet \bullet \bullet$ & & & & & $\bullet \bullet \bullet$ & \\
\hline $3-6-$ Rečkov & $\bullet \bullet \bullet$ & $\bullet \bullet$ & $\bullet \bullet$ & & $\bullet \bullet \bullet$ & & $\bullet \bullet$ \\
\hline $7-$ Klokočka & $\bullet \bullet \bullet$ & $\bullet \bullet$ & $\bullet \bullet \bullet$ & & $\bullet \bullet \bullet$ & & $\bullet \bullet$ \\
\hline 8- Hradčanský Rybník pond & & & $\bullet \bullet \bullet$ & & & $\bullet \bullet \bullet$ & \\
\hline $9-$ Máchovo Jezero pond & $\bullet \bullet \bullet$ & & & & & $\bullet \bullet \bullet$ & \\
\hline $10-11-$ Novozámecký Rybník pond & & & $\bullet \bullet \bullet$ & & & $\bullet \bullet \bullet$ & $\bullet \bullet \bullet$ \\
\hline Kokoŕínsko (BERAN in press) & $\bullet \bullet \bullet$ & $\bullet \bullet \bullet$ & $\bullet \bullet \bullet$ & $\bullet$ & $\bullet \bullet \bullet$ & $\bullet \bullet$ & $\bullet \bullet \bullet$ \\
\hline
\end{tabular}


In Moravia the species lives in two areas. In the Dyje River Basin in lowland wetlands (floodplain, borders of ponds and brooks) it inhabits similar habitats as in Bohemia but often also Typha swamps (FLASAR \& ZVARIČ 1966, ZVARIČ unpubl.). Small and isolated tufa-forming fens are the habitat of this snail in the White Carpathians. (HoRsÁK 2005).

Hydrological conditions are considered as the most important for surviving populations of this species. Potential problems are the conflict between management for the maintenance of this snail and management for vegetation maintenance, or in the case of lack of management, vegetation succession.

\section{References}

BERAN L., 1995: Vrkoč bažinný - druh z Červeného seznamu IUCN v České republice. [Desmoulin`s whorl snail - the species listed on the Red List of Threatened animals in the Czech Republic]. - Ochrana prírody, Praha, 3: 80-81.

BERAN L., 1998: Molluscs (Gastropoda; Bivalvia) of the wetlands in the Liběchovka and Pšovka brooks basin. - Časopis Národního muzea, Řada př́rodovědná, 167: 43-51.

BERAN L., in press: Měkkýši (Mollusca) CHKO Kokořínsko. [Molluscs (Mollusca) of the Kokořínsko Protected Landscape Area]. - In: Bezobratlí živočichové CHKO Kokořínsko. [Invertebrates of the Kokorínsko Protected Lanscape Area], BERAN L. (ed.) Bohemia centralis, Praha.

Cameron R.A.D., Colville B., Falkner G., Holyoak G.A., Hornung E., KilleEn I.J., MoOrkens E.A., PoKryszKo B.M., ProsChWitz T., TATTERSFiEld P. \& VALOVIRTA I.,
2003: Species Accounts for snails of the genus Vertigo listed in Annex II of the Habitat Directive: $V$. angustior, $V$. genesii, $V$. geyeri and $V$. moulinsiana (Gastropoda, Pulmonata: Vertiginidae). - Heldia, 5 (7): 151-170.

FlasAR I. \& ZVARIČ B., 1964: Neue Fundstellen dreier bemerkenswerter Schneckenarten in der Tschechoslowakei. - Malakologische Abhandlungen Staatliches Museum Tierkunde, 3: 245-251.

HorsÁK M., 2005: Molluscs. - In: Ecology and palaeoecology of spring fens in the western part of the Carpathians, PoulíčKovÁ A., HÁJEK M. \& RYBNÍČEK K. (eds) Palacký University, Olomouc, pp. 197-208.

KILLEEN I.J. 2003: A review of EUHSD Vertigo Species in England and Scotland (Gastropoda, Pulmonata: Vertiginidae). - Heldia 5 (7): 7384.

LOŽEK V., 1955: Měkkýši československého kvartéru. (Mollusken des Tschechoslovakischen Quartärs). - Rozpravy Ústředního ústavu geologického, Praha, 17: 1-510.

POKRYSZKO B.M., 1990: The Vertiginidae of Poland (Gastropoda: Pulmonata: Pupillidea) - a systematic monograph. - Annales zoologici, 43 (8): 133-257.

POKRYSZKO B.M., 2003: Vertigo of continental Europe - autecology, threat and conservation status (Gastropoda, Pulmonata: Vertiginidae). - Heldia, 5(7): 13-25.

PRUNER L. \& MíkA P. 1996: Seznam obcí a jejich částí v České republice s čísly mapových polí pro sít'ové mapování fauny [List of settlements in the Czech Republic with associated map field codes for faunistic grid mapping system]. - Klapalekiana, 32, Suppl.: 1-175. 